\title{
Quantitative estimation of Mycobacterium leprae in exhaled nasal breath
}

\author{
CHRISTINA A GREEN, * V M KATOCH† \\ $\& \mathrm{~K}$ V DESIKAN† \\ * School of Clinical Medicine, Cambridge, England; †Central \\ J ALMA Institute for Leprosy, Taj Ganj, Agra 282001, India
}

Accepted for publication 6 March 1983

\begin{abstract}
Summary A quantitative estimation of leprosy bacilli in exhaled nasal breath was undertaken in 20 patients of borderline and lepromatous leprosy. Out of the 20 patients, 8 were untreated, 6 had treatment for 1 month and the remaining 6 were on treatment for a period of 3 months. Non-cultivable acid-fast bacilli could be demonstrated in nasal breath in all the cases studied. The average number of bacilli excreted were $3.8 \times 10^{4}, 2.9 \times 10^{4}$ and $2.8 \times 10^{4}$ per breath in the 3 groups respectively. The quantum of bacilli exhaled increased with duration of the disease.
\end{abstract}

\section{Introduction}

It has been established for over 80 years that large numbers of Mycobacterium leprae are excreted from the nose and mouth in the majority of lepromatous cases of leprosy. It has also been shown that leprosy bacilli can be demonstrated in a large majority of such cases in nasal washings, ${ }^{12,13}$ nasal smears ${ }^{2}$ and in nasal blows, ${ }^{3}$ in the deep nasal breath. ${ }^{1}$ The positivity in mouth washings as well as in nasal smears has been studied. ${ }^{6}$ Together, these papers present a surge of interest directed recently towards evaluating the nose and mouth as exits for transmittable $M$. leprae. The present study was undertaken to find out if bacilli could be extruded through normal or just harsh breathing and if so the possible numbers of bacilli that could be thrown out in the environment.

\section{Material and methods}

The patients included in this study were selected from those attending the

* Present address: Renal Transplant Unit, Bristol, England.

$\dagger$ Reprints may be obtained from Dr Desikan. 
out-patient clinics at JALMA. They were all very advanced and highly bacillated cases. Of the 20 cases included in the present study, 19 belonged to the lepromatous type whereas one was of the BL type. ${ }^{11}$ Of these 8 were untreated, 6 had treatment for 1 month and the remaining 6 were on therapy for a period of 3 months.

Each patient was asked to breathe into a flask containing $10 \mathrm{ml}$ of physiological saline. In order to dislodge the bacilli from the glass surface, a few drops of $1 \%$ Tween 80 were added and the sides of the flask were washed down by swirling the fluid. The fluid was then centrifuged at $10,000 \mathrm{rpm}$ for 30 minutes. The supernatant was pipetted off and the remaining pellet was suspended in $1 \mathrm{ml}$ of physiological saline. The bacilli were counted and calculated according to the method of Hart \& Rees. ${ }^{5}$ The remaining suspension was decontaminated by modified Petroff's method as described by Shepard..$^{12}$ It was then inoculated into Lowenstein-Jensen medium to observe growth of any cultivable Mycobacteria. Absence of growth on Lowenstein-Jensen medium was taken as an indirect proof of the acid-fast bacilli being $M$. leprae. Slit smears were performed in the usual way from the ear lobes. Bacteriological Index (BI) was assessed and graded according to the method described by Dharmendra. ${ }^{4}$

\section{Results}

The number of bacilli per exhaled nasal breath is shown in Table 1. The untreated

Table 1. Bacilli exhaled in nasal breath and bacteriological indices of bacilli in skin smears

\begin{tabular}{|c|c|c|c|}
\hline & & Skin smears & Bacilli exhaled \\
\hline & patients & Mean $\mathrm{BI}^{*} \pm \mathrm{SD}$ & Mean number per breath \\
\hline $\begin{array}{l}\text { Group I } \\
\text { (Untreated) }\end{array}$ & 8 & $2 \cdot 1 \pm 0 \cdot 69$ & $\begin{array}{c}3 \cdot 8 \times 10^{4} \\
\left(2 \cdot 25 \times 10^{3}-1 \cdot 1 \times 10^{5}\right)(\mathrm{a}) \\
\text { range }\end{array}$ \\
\hline $\begin{array}{l}\text { Group II } \\
\text { (On treatment } \\
\text { up to } 1 \text { month) }\end{array}$ & 6 & $2 \cdot 0 \pm 0 \cdot 4$ & $\begin{array}{c}2 \cdot 9 \times 10^{4} \\
\left(2 \cdot 25 \times 10^{3}-7 \cdot 1 \times 10^{4}\right)(b) \\
\text { range }\end{array}$ \\
\hline $\begin{array}{l}\text { Group III } \\
\text { (On treatment } \\
\text { up to } 3 \text { months) }\end{array}$ & 6 & $2 \cdot 0 \pm 0 \cdot 5$ & $\begin{array}{c}2 \cdot 8 \times 10^{4} \\
\left(4.5 \times 10^{3}-1 \cdot 3 \times 10^{5}\right)(\mathrm{c}) \\
\text { range }\end{array}$ \\
\hline
\end{tabular}


group consisted of 6 men in the age group of 16-50 years and 2 women both aged 30 years. The mean duration of the disease was 7 years. The BI varied from $1+$ to $4+$, the mean being $2 \cdot 1+$. All of the patients exhaled bacilli in their nasal breath, the average number of bacilli being $3.8 \times 10^{4}$ per breath.

There were 6 patients who had received treatment for up to 1 month. All of them had received dapsone $50-100 \mathrm{mg}$ for 5 days to 1 month. Four patients were on combination therapy with clofazimine, pyrazinamide, thiacetazone and isoniazid. All were men belonging to the $22-50$-year age group. The average duration of illness in this group was 8 years. The mean BI was $2+$. Again bacilli could be found in the exhaled nasal breath in all of these patients, the average number being $2.9 \times 10^{4}$ per breath.

The third group comprised 6 cases whose mean period of treatment was $2 \frac{1}{2}$ months. As in the second group, all the patients had taken dapsone $50-100 \mathrm{mg}$. Two received other drugs also. All the patients in the group were men aged between 21 and 45 years and the mean duration of their illness was 8 years. The average number of bacilli extruded numbered $2.8 \times 10^{4}$ per breath.

Taking the duration of disease into consideration, it was seen that the number of bacilli in breath increased with duration of disease $(P<0 \cdot 05)$ (Table 2). There was no growth on the Lowenstein-Jensen medium in all the samples cultured.

Table 2. Relationship between the disease duration and exhalation of bacilli in nasal breath

\begin{tabular}{lcc}
\hline & $\begin{array}{c}\text { Disease duration } \\
<5 \text { years }\end{array}$ & $\begin{array}{c}\text { Disease duration } \\
>5 \text { years }\end{array}$ \\
\hline $\begin{array}{l}\text { Number of patients } \\
\text { Mean number of bacilli excreted }\end{array}$ & $\begin{array}{c}1.0 \times 10^{4} / \text { breath } \\
\text { Mean }\end{array}$ & $\begin{array}{c}12 \\
405 \times 10^{4} / \text { breath }\end{array}$ \\
\hline
\end{tabular}

Standard error $=2.56$ (on the basis of individual excretion rates and $P<0 \cdot 05)$.

\section{Discussion}

In the present study, non-cultivable acid-fast bacilli could be demonstrated in nasal breath of all the cases examined. Taking the absence of growth on Lowenstein-Jensen medium as a negative proof, these bacilli were considered in all probability to be Mycobacterium leprae. In one earlier study, ${ }^{3} 54 \%$ positivity was found in nasal discharges whereas in another ${ }^{6}$ bacilli were found in $50 \%$ of the cases in nasal smears. It must be mentioned that in the present study all the cases selected were highly bacillated patients with little or no treatment. Pedley ${ }^{7}$ and Pedley \& Geater ${ }^{8}$ have drawn attention to the importance of nasal secretions as the portal of exit of leprosy bacilli. While the presence of bacilli in the nasal 
secretions and nasal blows is well recognized, it was of interest to find bacilli even in slightly harsher breath in the very highly bacillated cases of lepromatous leprosy. The present study has shown that in advanced cases of lepromatous leprosy a sizeable number of bacilli are exhaled with a harsh breath. These observations support the findings of Bedi et al.' wherein they had described acid-fast bacilli in deep breath of multibacillary cases. There was no significant difference in the number of bacilli in untreated cases as compared with cases treated for 1 month or up to 3 months. On the other hand, there was a correlation with the duration of the disease, cases with longer duration extruding a larger number of bacilli. These observations would be underscored in view of the fact that the values are obtained from different groups of patients and not from the same group followed up with treatment.

It is clear from the studies carried out so far that a large number of leprosy bacilli could be excreted from the upper respiratory passages as assessed by the examination of the nasal smears, nasal blows and nasal breath. These findings signify the importance of nasal infection in the epidemiology of leprosy. ${ }^{3,9,10}$ However, none of these new findings need cause alarm to the patients or to the medico-social workers since it seems obvious that leprosy is only mildly contagious as judged by its low attack rate in the community.

\section{References}

${ }^{1}$ Bedi BMS, Narayan E, Sreevatsa, Kirchheimer WF, Balasubrahmanyam M. Dispersal of Mycobacterium leprae by leprosy patients while breathing. Ann Indian Acad Sci, 1976; 12: 1.

2 Davey TF, Barton RPE. Multiple nasal smears in leprosy. Lepr India, 1973; 45: 54.

3 Davey TF, Rees RJW. The nasal discharge in leprosy: clinical and bacteriological aspects. Lepr Rev, 1974; 45: 121.

${ }^{4}$ Dharmendra. Notes on Leprosy. Ministry of Health, Government of India, 1967; p. 314.

5 Hart P D'Arcy, Rees RJW. Effect of macrocyclon on acute and chronic pulmonary tuberculosis in mice as shown by viable and total bacterial counts. Br J exp Path, 1960; 41: 414.

${ }^{6}$ Hubscher S, Girdhar BK, Desikan KV. Discharge of Mycobacterium leprae from the mouth in lepromatous leprosy patients. Lepr Rev, 1979; 50: 45.

7 Pedley JC. Composite skin contact smears: a method of demonstrating the non-emergence of $M$. leprae from intact lepromatous skin. Lepr Rev, 1970; 41: 31.

8 Pedley JC, Geater JH. Does droplet infection play a role in the transmission of leprosy? Lepr Rev, 1976; 47: 97.

9 Rees RJW, Meade TW. Comparison of the modes of spread and incidence of tuberculosis and leprosy. Lancet, 1974; i: 47.

10 Rees RJW, Ridley DS. Bacteriology and Pathology of Leprosy, in 'Recent Advance in Clinical Pathology'; series 6 (S C Dyke edn). Edinburgh and London: Churchill Livingstone, 1973.

11 Ridley DS, Jopling WH. Classification of leprosy according to immunity. A five-group system. Int J Lepr, 1966; 34: 255.

12 Shepard CC. Acid-fast bacilli in nasal secretions in leprosy. The results of inoculation in mice. Amer J Hyg, 1960; 71: 147.

${ }_{13}$ Shepard CC. Nasal excretion of M. leprae in leprosy. Int J Lepr, 1962; 30: 10. 